\title{
HUBUNGAN USIA, PARITAS, PEKERJAAN DAN STRESS DENGAN EMESIS GRAVIDARUM DI KOTA BANDAR LAMPUNG
}

\author{
Novita Rudiyanti*, Rosmadewi* \\ *Jurusan Kebidanan Poltekkes Tanjungkarang \\ Email: rudiyantinovita@yahoo.com
}

\begin{abstract}
Emesis gravidarum, dialami oleh sekitar 70-80\% wanita hamil, pada 60-80\% primigravida dan 40-60\% multigravida. Faktor yang mempengaruhi yaitu usia, kurang dari 20 tahun dan diatas 35 tahun dan muntah terjadi pada umur dibawah 20 dan diatas 35 tahun terjadi akibat faktor psikologis. Ibu yang bekerja sebanyak 36 orang $(55,4 \%)$, sedangkan ibu yang tidak bekerja sebanyak 29 orang $(44,6 \%)$. Masalah dalam penelitian ini adalah angka kejadian emesis gravidarum pada trimester pertama menunjukkan persentase yang cukup tinggi yaitu sebanyak $66 \%$ pada trimester pertama mengalami mual dan gejala yang sering terjadi pada 60-80 \% primigravida dan 40-60\% multigravida, usia yang bervariasi, kondisi psikologis yang berbeda-beda.Tujuan penelitian adalah mengetahui Hubungan dari Usia, Paritas, Pekerjaan dan Stress dengan Emesis Gravidarum di Kota Bandar Lampung. Penelitian analitik dengan pendekatan cross sectional, dilakukan pada bulan Oktober - Desember 2018, sampel adalah 90 orang, alat pengumpulan data adalah kuesioner dengan tehnik angket. Analisis data adalah univariat, bivariat menggunakan Chi square serta multivariat. Hasil penelitian yaitu dari 90 responden terdapat usia beresiko $70 \%$, multigravida 62,2\%, Bekerja 51,1\%, tidak stress 56,7\%. Ada hubungan yang signifikan antara usia, pekerjaan dan stress dengan Emesis Gravidarum. Variabel yang paling dominan adalah Pekerjaan. Peneliti menyarankan melakukan konseling pra nikah dan saat ANC tentang pengetahuan perubahan fisiologis kehamilan terutama rasa mual dan muntah yang dialami saat trimester I menjadi lebih baik dan kondisi psikologis ibu lebih siap untuk menerima kehamilannya.
\end{abstract}

Kata kunci: Emesis, Usia, Paritas, Pekerjaan, Stress

\section{LATAR BELAKANG}

Mual muntah pada kehamilan umumnya disebut emesis gravidarum, dialami oleh sekitar 70-80\% wanita hamil dan merupakan fenomena yang sering terjadi pada umur kehamilan 5-12 minggu (Runiari 2010). Wanita hamil sebanyak $66 \%$ pada trimester pertama mengalami mual dan gejala yang sering terjadi pada 60-80 \% primigravida dan 40-60\% multigravida, namun sekitar $12 \%$ ibu hamil masih mengalami mual muntah hingga sampai usia kehamilan sembilan bulan (Suwarni, 2007). Menurut Supriyanto (2009), 50-90\% wanita hamil mengalami mual pada trimester pertama dan sekitar $25 \%$ wanita hamil mengalami masalah mual muntah memerlukan waktu untuk beristirahat dari pekerjaannya (Smith, dkk, 2009).

Mual dan muntah yang berlebihan dan terjadi sepanjang hari sampai menganggu pekerjaan sehari-hari, menyebabkan dehidrasi dan kehilangan berat badan lebih dari $5 \%$ berat badan sebelum hamil disebut sebagai hiperemesis gravidarum (Fauziah, 2012). Hiperemesis gravidarum berhubungan dengan ketidakseimbangan cairan dan elektrolit. Sering kali apabila menderita hiperemesis gravidarum dibutuhkan perawatan Rumah Sakit. Hiperemesis gravidarum biasanya muncul pada 4-8 minggu kehamilan dan berlanjut sampai 1416 minggu masa kehamilan. Jika tidak diobati, atau jika pengobatan tidak berhasil, emesis gravidarum kasus berat dapat menyebabkan efek negatif pada janin, seperti berat badan lahir rendah dan prematuritas (Veenendal, 2011). Hal ini juga bisa mengakibatkan kematian ibu.

Penyebab terjadinya emesis gravidarum sampai saat ini tidak dapat diketahui secara jelas, akan tetapi mual dan muntah dianggap sebagai masalah multifaktorial. Teori berkaitan adalah faktor hormonal, sistem vestibular, pencernaan, 
psikologis, hiperolfaction, dan genetik. Berdasarkan suatu studi prospektif pada 9000 wanita hamil yang mengalami mual muntah, didapatkan hasil risiko mual muntah meningkat pada primigravida, wanita yang pendidikannya kurang, merokok, kelebihan berat badan atau obesitas, memiliki riwayat mual dan muntah pada kehamilan sebelumnya. Mual dan muntah merupakan interaksi yang kompleks dari pengaruh endokrin, pencernaan, faktor vestibular, penciuman, genetik, psikologi.

Kejadian emesis gravidarum dialami oleh sebagian besar ibu hamil baik primigravida maupun multigravida. Emesis gravidarum terjadi pada $60-80 \%$ primigravida dan $40-60 \%$ multigravida.

Faktor selanjutnya yang juga mempengaruhi kejadian emesis gravidarum yaitu usia, dimana usia yang termasuk dalam kehamilan berisiko tinggi adalah kurang dari 20 tahun dan diatas 35 tahun.dan muntah terjadi pada umur dibawah 20 dan diatas 35 tahun terjadi akibat faktor psikologis (Manuaba, 2007). Ibu yang bekerja sebanyak 36 orang $(55,4 \%)$, sedangkan ibu yang tidak bekerja sebanyak 29 orang $(44,6 \%)$ (Anggraena, 2012). Kehamilan yang tidak direncanakan, tidak nyaman atau tidak diinginkan, beban pekerjaan akan menyebabkan penderitaan batin dan konflik. Perasaan bersalah, marah, ketakutan dan cemas dapat menambah gejala fisik. Kurang pengetahuan, informasi dan komunikasi yang buruk antara wanita dan pemberi asuhannya turut mempengaruhi persepsi wanita tentang keparahan gejala (Jojor, 2011)

Deteksi dini faktor resiko atau penyebab dan Penanganan yang tepat pada emesis gravidarum dapat menurunkan kejadian hiperemesis gravidarum. Salah satu cara yaitu dengan melakukan ANC yang berkualitas ke fasilitas kesehatan. Puskesmas Waykandis merupakan salah satu fasilitas pelayanan kesehatan yang memberikan pelayanan ANC. Namun tidak hanya di Puskesmas tapi juga di Bidan Praktik Mandiri bisa mendapatkan pelayanan ANC. Puskesmas Waykandis memiliki sasaran ibu hamil yang cukup banyak dengan variasi karakteristik yang heterogen. Latar belakang usia, pekerjaan, pendidikan dan paritas juga beraneka ragam.

\section{METODE}

Desain penelitian ini menggunakan survei analitik dengan pendekatan cross sectional. Populasi dalam penelitian ini adalah ibu hamil pada wilayah kerja salah satu Puskesmas di Kota Bandar Lampung. Sampel penelitian berjumlah 90 orang dengan teknik accidental sampling. Jenis data yang diambil dalam penelitian ini adalah data primer yaitu data yang diperoleh langsung dari responden. Pengumpulan data dilakukan secara angket dengan kuisioner. Pengolahan data melalui tahap editing, coding, processing dan cleaning. Analisis data secara univariat, bivariat serta multivariate.

\section{HASIL}

Tabel 1: Distribusi Frekuensi Responden Berdasarkan Usia, Paritas, Pekerjaan, Stress dan Emesis Pada Ibu Hamil

\begin{tabular}{lcc}
\hline \multicolumn{1}{c}{ Variabel } & $\mathrm{f}$ & $\%$ \\
\hline Usia & & \\
\hline Beresiko & 27 & 30 \\
\hline Tidak Beresiko & 63 & 70 \\
\hline Paritas & & \\
\hline Primigravida & 34 & 37,8 \\
\hline Multigravida & 56 & 62,2 \\
\hline Pekerjaan & & \\
\hline Bekerja & 44 & 48,9 \\
\hline Tidak Bekerja & 46 & 51,1 \\
\hline Stress & & \\
\hline Stress & 39 & 43,3 \\
\hline Tidak Stress & 51 & 56,7 \\
\hline Emesis & \\
\hline Tidak Normal & 46 & 51,1 \\
\hline Normal & 44 & 48,9 \\
\hline Total & 90 & 100.0 \\
\hline
\end{tabular}

Berdasarkan hasil penelitian untuk variabel usia menunjukan bahwa lebih banyak responden yang memiliki usia tidak beresiko (usia $20-35$ tahun) yaitu $70 \%$, lebih banyak responden yang memiliki status 
multigravida (kehamilan lebih dari 1 kali) yaitu $62,2 \%$, jumlah antara ibu hamil yang bekerja dan tidak bekerja hampir seimbang yaitu bekerja sebanyak 48,9\% dan tidak bekerja sebanyak $51,1 \%$, separuh ibu hamil mengalami stress sebanyak 56,7\%, dan separuh ibu hamil mengalami emesis tidak normal sebanyak $51,1 \%$.

\section{Analisis Bivariat}

Tabel 2: Distribusi Responden Menurut Usia dan Emesis Gravidarum

\begin{tabular}{lcccccc}
\hline \multirow{2}{*}{ Usia } & \multicolumn{3}{c}{ Emesis Gravidarum } & & \multirow{2}{*}{ Total } \\
\cline { 2 - 5 } & \multicolumn{2}{c}{$\begin{array}{c}\text { Tidak } \\
\text { Normal }\end{array}$} & \multicolumn{2}{c}{ Normal } & & \\
\cline { 2 - 6 } & $\mathrm{f}$ & $\%$ & $\mathrm{f}$ & $\%$ & $\mathrm{f}$ & $\%$ \\
\hline Beresiko & 19 & 70,4 & 8 & 29,6 & 27 & 100 \\
\hline $\begin{array}{l}\text { Tidak } \\
\text { Beresiko }\end{array}$ & 27 & 42,9 & 36 & 57,1 & 63 & 100 \\
\hline Total & 46 & 51,1 & 44 & 48,9 & 90 & 100 \\
\hline$p$ value & 0,031 & & & & & \\
\hline OR & 3,16 & & & & & \\
\hline
\end{tabular}

Hasil analisis hubungan antara usia dengan emesis gravidarum diperoleh bahwa diantara responden yang mengalami emesis gravidarum tidak normal terdapat 70,4 \% (19 org) yang usia beresiko (usia < 20 tahun dan $>35$ tahun) dan 42,9\% (27 org) yang usia tidak beresiko (usia 20 - 35 tahun). Hasil uji statistik diperoleh nilai $p$ value $=0,031$, disimpulkan secara statistik ada hubungan yang antara usia dengan emesis gravidarum. Berdasarkan hasil analisis diperoleh pula nilai $O R=3,167$, artinya responden yang mempunyai usia beresiko mempunyai peluang 3,167 kali untuk mengalami emesis gravidarum tidak normal dibandingkan dengan responden yang usia tidak beresiko.
Tabel 3: Distribusi Responden Menurut Paritas dan Emesis Gravidarum

\begin{tabular}{lcccccc}
\hline \multirow{3}{*}{ Paritas } & \multicolumn{3}{c}{ Emesis Gravidarum } & \multirow{2}{*}{ Total } \\
\cline { 2 - 6 } & $\begin{array}{l}\text { Tidak } \\
\text { Normal }\end{array}$ & \multicolumn{2}{c}{ Normal } & & \\
& $\mathrm{f}$ & $\%$ & $\mathrm{f}$ & $\%$ & $\mathrm{f}$ & $\%$ \\
\hline Primigravida & 20 & 58,8 & 14 & 41,2 & 34 & 100 \\
\hline Multigravida & 26 & 46,4 & 30 & 53,6 & 56 & 100 \\
\hline Total & 46 & 51,1 & 44 & 48,9 & 90 & 100 \\
\hline$p$ value & 0,356 & & & & \\
\hline
\end{tabular}

Hasil analisis hubungan antara paritas dengan emesis gravidarum diperoleh bahwa diantara responden yang mengalami emesis gravidarum tidak normal terdapat 58,8\% yang primigravida (kehamilan pertama) dan 46,4\% yang multigravida (kehamilan kedua dan seterusnya). Hasil uji statistik diperoleh nilai $p$ value $=0,356$, disimpulkan secara statistik tidak ada hubungan yang signifikan antara paritas dengan emesis gravidarum.

Tabel 4: Distribusi Responden Menurut Pekerjaan dan Emesis Gravidarum

\begin{tabular}{|c|c|c|c|c|c|c|}
\hline \multirow{3}{*}{ Pekerjaan } & \multicolumn{4}{|c|}{ Emesis Gravidarum } & \multirow{2}{*}{\multicolumn{2}{|c|}{ Total }} \\
\hline & \multicolumn{2}{|c|}{$\begin{array}{c}\text { Tidak } \\
\text { Normal }\end{array}$} & \multicolumn{2}{|c|}{ Normal } & & \\
\hline & $f$ & $\%$ & $\mathrm{f}$ & $\%$ & $\mathrm{f}$ & $\%$ \\
\hline Bekerja & 31 & 70,5 & 13 & 29,5 & 44 & 100 \\
\hline Tidak Bekerja & 15 & 32,6 & 31 & 67,4 & 46 & 100 \\
\hline Total & 46 & 51,1 & 44 & 48,9 & 90 & 100 \\
\hline p value & \multicolumn{6}{|c|}{0,001} \\
\hline OR & \multicolumn{6}{|c|}{4,92} \\
\hline
\end{tabular}

Hasil analisis hubungan antara pekerjaan dengan emesis gravidarum diperoleh bahwa diantara responden yang mengalami emesis gravidarum tidak normal terdapat $70,5 \%$ (31 org) yang bekerja dan $32,6 \%$ (15 org) yang tidak bekerja. Hasil uji statistik diperoleh nilai $p$ value $=0,001$, disimpulkan secara statistik ada hubungan yang signifikan antara pekerjaan dengan emesis gravidarum. Berdasarkan hasil analisis diperoleh pula nilai $O R=4,928$, artinya responden yang mempunyai pekerjaan mempunyai peluang 4,928 kali untuk mengalami emesis gravidarum tidak normal dibandingkan dengan responden yang tidak bekerja. 
Tabel 5: Distribusi Responden Menurut Stress dan Emesis Gravidarum

\begin{tabular}{ccccccc}
\hline \multirow{3}{*}{ Stress } & \multicolumn{3}{l}{ Emesis Gravidarum } & \multirow{2}{*}{ Total } \\
\cline { 2 - 5 } & $\begin{array}{c}\text { Tidak } \\
\text { Normal }\end{array}$ & \multicolumn{2}{c}{ Normal } & & \\
\cline { 2 - 6 } & $\mathrm{f}$ & $\%$ & $\mathrm{f}$ & $\%$ & $\mathrm{f}$ & $\%$ \\
\hline Stress & 28 & 71,8 & 11 & 28,2 & 39 & 100 \\
\hline Tidak Stress & 18 & 35,3 & 33 & 64,7 & 51 & 100 \\
\hline Total & 46 & 51,1 & 44 & 48,9 & 90 & 100 \\
\hline$p$ value & 0,001 & & & & \\
\hline OR & 4,667 & & & & \\
\hline
\end{tabular}

Hasil analisis hubungan antara stress dengan emesis gravidarum diperoleh bahwa diantara responden yang mengalami emesis gravidarum tidak normal terdapat $71,8 \%$ (28 org) yang stress dan 35,3\% (18 org) yang tidak stress. Hasil uji statistik diperoleh nilai $p$ value $=0,001$, disimpulkan secara statistik ada hubungan yang signifikan antara pekerjaan dengan emesis gravidarum. Berdasarkan hasil analisis diperoleh pula nilai $O R=4,667$, artinya responden yang mengalami stress mempunyai peluang 4,667 kali untuk mengalami emesis gravidarum tidak normal dibandingkan dengan responden yang tidak stress.

\section{Analisis Multivariat}

\section{Tabel 6: Pemodelan Akhir Analisis Multivariat Regresi Logistik}

\begin{tabular}{cccccccc}
\hline \multicolumn{8}{c}{ Variabel dalam Persamaan } \\
\hline & B & S.E. & Wald & df & Sig. & $\operatorname{Exp}(\mathrm{B})$ \\
\hline \multirow{2}{*}{$\begin{array}{c}\text { Step Usia } \\
1^{\mathrm{a}}\end{array}$} & 1.156 & .563 & 4.217 & 1 & .040 & 3.176 \\
\cline { 2 - 8 } & Pekerjaan & 1.600 & .502 & 10.144 & 1 & .001 & 4.954 \\
\cline { 2 - 8 } & Stress & 1.378 & .505 & 7.450 & 1 & .006 & 3.966 \\
\cline { 2 - 7 } & Constant & -2.492 & .654 & 14.513 & 1 & .000 & .083 \\
\hline
\end{tabular}

Hasil analisis setelah variabel paritas dikeluarkan perubahan OR tidak ada yang > $10 \%$ sehingga ini merupakan model akhir. Jenis penelitian ini adalah cross sectional sehingga hasil analisis multivariat hanya menjelaskan nila OR (Exp B). Hasil analisis multivariat didapatkan variabel usia mempunyai nilai OR 3,1 artinya ibu yang mempunyai usia beresiko akan mengalami emesis gravidarum tidak normal sebesar 3 kali lebih tinggi dibandingkan ibu yang mempunyai usia tidak beresiko setelah dikontrol variabel pekerjaan dan stress. Variabel pekerjaan mempunyai nilai OR 4,9 artinya ibu yang mempunyai pekerjaan akan mengalami emesis gravidarum tidak normal sebesar 4 kali lebih tinggi dibandingkan ibu yang tidak bekerja setelah dikontrol variabel usia dan stress. Variabel stress mempunyai nilai OR 3,9 artinya ibu yang stress akan mengalami emesis gravidarum tidak normal sebesar 3 kali lebih tinggi dibandingkan ibu yang tidak stress setelah dikontrol variabel usia dan pekerjaan.

\section{PEMBAHASAN}

Pada variabel usia, hasil penelitian menunjukan bahwa lebih banyak responden yang memiliki usia tidak beresiko yaitu $70 \%$. Hal ini berarti lebih banyak responden yang berusia antara 20 - 35 tahun sehingga dalam aktegori usia sehat untuk bereproduksi. Namun terdapat $30 \%$ responden yang mempunyai usia beresiko yaitu usia $<20$ tahun dan lebih dari 35 tahun. Responden yang mempunyai usia beresiko terdapat 4 orang dengan usia $<20$ tahun yaitu usia 19 tahun dan 15 tahun, serta 5 orang dengan usia $>40$ tahun yaitu 41 tahun dan 44 tahun.

Usia adalah lama waktu hidup atau ada (sejak dilahirkan atau diadakan). Dalam kurun reproduksi sehat dikenal bahwa usia aman untuk kehamilan dan persalinan adalah 20 tahun sampai dengan 35 tahun. Kehamilan pada usia kurang dari 20 tahun panggul dan rahim masih kecil, perkembangan organorgan reproduksi yang belum optimal, kematangan emosi dan kejiwaan kurang serta fungsi fisiologi yang belum optimal, sehingga lebih sering terjadi komplikasi yang tidak diinginkan dalam kehamilan. Pada usia di atas 35 tahun, organ reproduksi dan fungsi fisiologis mengalami penurunan dibandingkan pada saat umur 20-35 tahun. Penelitian-penelitian awal mengisyaratkan bahwa wanita berusia lebih dari 35 tahun berisiko lebih tinggi mengalami penyulit obstetris serta morbiditas dan mortalitas perinatal (Manuaba, 2007). Pada masa 
reproduksi, usia ibu mempengaruhi hasil akhir kehamilan. Menurut National Center for Health Statistics (NCHS), sekitar 13 persen persalinan terjadi pada wanita berusia antara 15 sampai 19 tahun. Remaja adalah penduduk dalam rentang usia 10-19 tahun. Remaja memiliki kemungkinan lebih besar mengalami anemia, dan berisiko lebih tinggi memiliki janin yang pertumbuhannya terhambat, persalinan prematur, dan angka kematian bayi yang lebih tinggi (Manuaba, 2007).

Kejadian kehamilan di usia dini atau $<20$ tahun dan kehamilan di usia lanjut atau $>35$ tahun, memiliki resiko lebih tinggi dibandingkan dengan usia reproduksi sehat. Kondisi alat reproduksi yang belum sempurna dan kesiapan psikologis untuk menjadi seorang ibu sangat kurang terjadi pada remaja. Hal ini memerlukan dukungan penuh dari keluarga dan petugas kesehatan untuk pendampingan selama hamil dan kelahiran agar kondisi ibu dan bayi sehat dan sejahtera. Pengaruh lingkungan sosial menjadi penyebab terbesar terjadinya kehamilan di usia dini. Sedangkan kehamilan di usia lanjut penyebabnya kegagalan ber$\mathrm{KB}$, pernikahan di usia tua, keinginan mempunyai anak dengan jenis kelamin tertentu serta kepercayaan yang dianut keluarga. Berdasarkan hal tersebut sangat tidak dianjurkan terjadi kehamilan diusia < 20 tahun dan $>35$ tahun.

Pada variabel Paritas, berdasarkan hasil penelitian menunjukan bahwa lebih banyak responden yang memiliki status multigravida (kehamilan lebih dari 1 kali) yaitu $62,2 \%$. Sedangkan primigravida sebesar 37,8\%. Pada responden yang multigravida dengan jumlah anak yang pernah dilahirkan 7 orang sebanyak 1 orang dan memiliki usia 44 tahun. Paritas adalah jumlah kehamilan yang menghasilkan janin yang mampu hidup diluar rahim (28 minggu) (JHPIEGO, 2008). Menurut Prawirohardjo (2009), paritas dapat dibedakan menjadi primipara, multipara dan grandemultipara.

Kondisi paritas yang beresiko mengalami komplikasi adalah paritas dengan jumlah anak yang dilahirkan $>5$ orang. Hal ini disebut grandemultipara. Kondisi rahim yang sudah berkali-kali mengalami kehmailan dan persalinan rentan terhadap atonia uteri sehingga perdarahan yang banyak beresiko terjadi kematian bagi ibu. Didukung pula kejadian grandemultipara pada usia lebih dari 35 tahun, sehingga fungsi rahim tidak maksimal seperti saat usia reproduksi sehat 20-35 tahun.

Pada variabel Pekerjaan, berdasarkan hasil penelitian menunjukan bahwa jumlah antara ibu hamil yang bekerja dan tidak bekerja hampir seimbang yaitu bekerja sebanyak 48,9\% dan tidak bekerja sebanyak $51,1 \%$. Pekerjaan merupakan suatu yang penting dalam kehidupan dengan bekerja kita bias memenuhi kebutuhan (Winknjosastro, 2005). Definisi bekerja yaitu responden melakukan kegiatan di rumah atau di tempat lain secara rutin atau berkala dengan tujuan untuk mendapatkan uang (Suniarti, 2007). Jenis pekerjaan yang dilakukan responden adalah karyawan swasta, pedagang, buruh dan PNS. Pekerjaan yang memiliki beban berat adalah karyawan swasta, buruh dan pedagang pasar.

Berkaitan dengan kondisi kehamilan pada wanita yang bekerja, tidak dianjurkan jika beban fisik pekerjaan tersebut cukup berat, begitu juga jika efek stress akibat beban kerja juga tidka dianjurkan. Kehamilan merupakan kejadian fisiologis dengan hormon yang berperan dalam perkembangan bayi dan ibu. Hormon yang berperan adalah estrogen dan progesteron. Pengeluaran hormon ini diatur oleh hipotalamus yang ada di otak manusia. Jika beban pikiran ibu selama hamil cukup berat amaka akan berpengaruh terhadap keseimbangan pengeluaran hormon tersebut.

Pada variabel Stress, berdasarkan hasil penelitian menunjukan bahwa separuh ibu hamil mengalami stress sebanyak 56,7\%. Stres adalah suatu kondisi tegangan (tension) baik secara faal maupun psikologis yang di sebabkan oleh tuntutan dari lingkungan yang dipersepsi kan oleh penderitanya sebagai ancaman. Secara umum kondisi psikologis ibu hamil cukup labil. Ia dapat memiliki reaksi yang ekstrem dan susana hatinya kerap berubah dengan cepat. Reaksi emosional dan persepsi mengenai kehidupan juga dapat mengalami perubahan. Ia menjadi sangat sensitif dan cenderung bereaksi 
berlebihan. Seorang wanita hamil akan lebih terbuka terhadap dirinya sendiri dan suka berbagi pengalaman kepada orang lain (Bobak, Lowdermilk, \& Jensen, 2005).

Responden yang mengalami stress sebanyak 11 orang yang bekerja. Pekerjaan yang memerlukan pemikiran penuh memicu terjadinya stress pada ibu hamil. Selain itu juga secara fisiologis terjadi perubahan kondisi psikologis yang berbeda-beda tiap trimester. Depresi ringan merupakan hal yang umum terjadi dan wanita dapat menjadi lebih bergantung pada orang lain lebih lanjut dan lebih menutup diri karena perasaan rentannya. Wanita akan kembali merasakan ketidaknyamanan fisik yang semakin kuat menjelang akhir kehamilan.

Pada variabel emesis, berdasarkan hasil penelitian menunjukan bahwa separuh ibu hamil mengalami emesis tidak normal sebanyak $51,1 \%$. Emesis yang tidak normal ini menunjukan frekuensi muntah lebih dari 4 kali dan mengalami penurunan berat badan $>$ $5 \%$. hal ini merupakan kondisi hiperemesis gravidarum jika terjadi tanda-tanda ibu hamil mengalami dehidrasi. Morning sickness disebut juga sakit pagi adalah gejala muntah (emesis gravidarum), biasanya terjadi pada pagi hari (Rustam, 2002). Mual dan muntah dalam kehamilan disebut sebagai morning sickness, biasanya terjadi pada 75-80\% wanita hamil. Meskipun sering disebut sebagai morning sick- ness, namun hanya $17 \%$ wanita hamil yang mengalami muntah pada pagi hari, sebagian besar wanita hamil mengalami mual muntah sepanjang hari. Sebagian besar mual dan muntah dapat hilang sendiri, namun sekitar 1-3\% mual dan muntah pada wanita hamil dapat berkembang menjadi mual dan muntah berat, yang biasa disebut sebagai hiperemesis gravidarum.

\section{Hubungan Usia dengan Emesis Gravidarum}

Hasil analisis hubungan antara usia dan emesis disebutkan bahwa diantara responden yang mengalami emesis gravidarum tidak normal terdapat 70,4\% (19 org) yang usia beresiko (usia $<20$ tahun dan $>35$ tahun) dan 42,9\% (27 org) yang usia tidak beresiko (usia 20 - 35 tahun). Hasil uji statistik diperoleh nilai $P$-value $=0,031$, disimpulkan secara statistik ada hubungan yang signifikan antara usia dengan emesis gravidarum. Berdasarkan hasil analisis diperoleh pula nilai $O R=3,167$, artinya responden yang mempunyai usia beresiko mempunyai peluang 3,167 kali untuk mengalami emesis gravidarum tidak normal dibandingkan dengan responden yang usia tidak beresiko.

Penelitian ini sama dengan penelitian Claudia Wijaya, 2017, dimana hasil penelitian menunjukkan presentase tertinggi terdapat pada ibu hamil kategori umur berisiko dan mengalami emesis berisiko berjumlah 16 responden $(88,9 \%)$. Hasil uji koefisien kontingensi didapatkan nilai $\mathrm{p}=0,006$ atau $(<0,05)$. Hal ini menunjukkan adanya hubungan yang bermakna antara umur berisiko dengan emesis berisiko. Penelitian Rosdiana Said 2013 diperoleh data bahwa responden terbanyak berjumlah 21 responden $(58.3 \%)$ yang tergolong kategori beresiko rendah terhadap kejadian emesis gravidarum apabila dinilai dari rentang umur 20 - 35 tahun dan terdapat pula 15 responden (41.7\%) tergolong kategori beresiko tinggi terhadap kejadian emesis gravidarum apabila dinilai dari umur $<20$ tahun. Hasil uji statistik memperlihatkan bahwa ada hubungan yang bermakna (signifikan) antara usia dengan kejadian emesis gravidarum pada ibu primigravida di Puskesmas KassiKassi Makassar dengan nilai signifikansi lebih kecil dari $5 \%(\mathrm{p}=0.000<0.05)$.

Namun penelitian ini tidak sejalan dengan Yunia mariantari, dkk, 2014, Hasil penelitian menunjukkan kejadian emesis sebesar $71,1 \%$. Analisa mengenai hubungan usia ibu terhadap kejadian emesis gravidarum didapatkan $p$ value 0,23 dimana $p$-value $>0,05$. Hal ini berarti tidak ada hubungan antara usia ibu terhadap kejadian emesis gravidarum.

Fenomena yang terjadi pada penelitian ini, usia ibu yang beresiko mengalami emesis normal sebesar 29,6\% (8 orang) dan usia tidak beresiko sebanyak 57,1\% (36 orang). Pada penelitian ini terdapat 12 orang (15\%) ibu yang mengalami emesis gravidarum tidak normal yaitu hiperemesis gravidarum. Hal ini terjadi pada rentang usia ibu hamil dalam kategori usia reproduksi 
sehat (20-35 tahun). Dilihat dari karakteristik responden, ibu hamil yang mempunyai usia beresiko terutama > 35 tahun mempunyai latar belakang pendidikan yang baik sehingga memiliki pengetahuan cukup tentang kesiapan menghadapi kehamilan. Ketenangan psikologis yang di dapatkan membuat rasa mual dan muntah ini dapat di adaptasi dengan baik sehingga tidak berlanjut ke kondisi tidak normal. Selain itu status pekerjaan juga lebih banyak ibu yang tidak bekerja sehingga beban pikiran akibat pekerjaan yang membuat ibu stress menjadi sedikit. Hal ini juga menurunkan kejadian emesis yang tidak normal.

\section{Penyebab terjadinya emesis} gravidarum yaitu perubahan psikologis, stimulasi hormonal, adaptasi evolusi, pekerjaan, paritas dan usia. Secara fisiologis mual dan muntah dalam kehamilan terjadi karena perubahan level hormon terutama beta human chorionic gonadotropin hormone (b-HCG), estradiol, dan progesteron. Hubungan antara mual dan muntah dalam kehamilan dengan b-HCG dapat dilihat jelas pada kehamilan kembar atau mola hidatidosa, kadar b-HCG lebih tinggi dari pada kehamilan normal. Estrogen, terutama estradiol, juga diduga mempunyai peranan pada mual dan muntah kehamilan. Suatu penelitian mendemonstrasikan bahwa wanita dengan hiperemesis gravidarum menunjukkan peningkatan level estradiol pada trimester pertama kehamilan. Perubahan hormon kehamilan juga bisa mengganggu fungsi neuromuskular dari sistem gastrointestinal, yang berakibat pada mual dan muntah. Perubahan hormonal ini terjadi pada semua ibu hamil tanpa memandang usia, tergantung kesiapan psikologis dan status gizi dari ibu hamil tersebut.

Mual dan muntah terjadi pada umur dibawah 20 tahun dan diatas 35 tahun terjadi akibat faktor psikologis. Masalah psikologis dapat memprediksi beberapa wanita untuk mengalami mual dan muntah dalam kehamilan, atau memperburuk gejala yang sudah ada atau mengurangi kemampuan untuk mengatasi gejala. Kehamilan yang tidak direncanakan, tidak nyaman atau tidak diinginkan, atau karena beban pekerjaan atau finansial akan menyebabkan penderitaan batin, ambivalensi, dan konflik. Kecemasan berdasarkan pengalaman melahirkan sebelumnya, terutama kecemasan akan datangnya hiperemesis gravidarum atau preeklamsia.

Maka dapat disimpulkan bahwa kehamilan dengan usia 20-35 tahun merupakan usia terbaik untuk mencegah terjadinya emesis gravidarum yang tidak normal. Namun jika terjadi kehamilan di usia $<20$ tahun dan $>35$ tahun diharapkan ibu hamil memiliki pengetahuan yang cukup agar dapat memahami cara mengatasi emesis, kondisi psikologis yaang stabil dengan adanya dukungan keluarga dan pendampingan tenaga kesehatan agar perubahan psikologis ibu tidak ekstrim dan pengeluaran hormon dapat seimbang yang akhirnya tidak memicu terjadinya emesis berlebihan.

\section{Hubungan Paritas Dengan Emesis Gravidarum}

Hasil analisis hubungan antara paritas dengan emesis gravidarum diperoleh bahwa diantara responden yang mengalami emesis gravidarum tidak normal terdapat 58,8 \% (20 org) yang primigravida (kehamilan pertama) dan 46,4\% (26 org) yang multigravida (kehamilan kedua dan seterusnya). Hasil uji statistik diperoleh nilai $P$ - value $=0,356$, disimpulkan secara statistik tidak ada hubungan yang signifikan antara paritas dengan emesis gravidarum.

Hal ini tidak sejalan dengan penelitian Vicky Elsa menunjukkan kejadian emesis gravidarum pada ibu hamil trimester I sebesar $42,86 \%$. Paritas terbanyak adalah multigravida sebesar 55,36\%. Hasil analisa data menggunakan chi square menunjukkan adanya hubungan yang bermakna $x$ Hitung $(8,25)>x$ tabel $(3,481)$. Penelitian Yunia mariantari, dkk, 2014, menunjukkan responden yang mengalami emesis gravidarum merupakan primigravida. Berdasarkan hasil uji statistik, diketahui ada hubungan gravida dengan kejadian emesis. Claudia Wijaya, 2017. Hasil penelitian menunjukkan, presentase tertinggi terdapat pada ibu hamil primigravida dan mengalami emesis berisiko berjumlah 34 responden 
$(87,2 \%)$. Hasil uji koefisien kontingensi didapatkan nilai $\mathrm{p}=0,000 \quad(<0,05)$ yang menunjukkan adanya hubungan yang bermakna antara primigravida dengan emesis berisiko.

Pada sebagian besar primigravida belum mampu beradaptasi dengan hormon estrogen dan chorionik gonadotropin sehingga lebih sering terjadi emesis gravidarum. Sedangkan pada multigravida sudah mampu beradaptasi dengan hormon estrogen dan chorionik gonadotropin karena sudah mempunyai pengalaman terhadap kehamilan dan melahirkan. Hal ini dibuktikan melalui penelitian yang dilakukan oleh Masruroh dan Ikke (2016) dimana terdapat hubungan yang signifikan antara status gravida dengan kejadian emesis gravidarum.

Pada penelitian ini responden yang mengalami emesis normal sebanyak $41,2 \%$ (14 orang) yang primigravida dan 53,6\% (30 orang) yang multigravida. Kondisi multigravida responden rentang jumlah anak 2-4 orang, sedangkan yang status grandemultiparitas dengan jumlah anak $>5$ sebanyak 1 orang. Pada responden yang primigravida rentang usia 20-35 tahun, hanya 3 orang yang usia $<20$ tahun. Latar belakang pendidikan primigravida rentang SMA dan Sarjana, hal ini mendukung untuk baiknya pengetahuan ibu sehingga informasi seputar kehamilan sudah ia dapatkan. Kesiapan psikologis setelah mendapatkan pengetahuan yang baik akan menurunkan kejadian emesis gravidarum. Frekuensi pemeriksaan kehamilan pada primigravida juga lebih baik dibandingkan dengan multigravida. Dengan seringnnya berkomunikasi dengan petugas kesehatan maka kekhawatiran ibu hamil yang memicu terjadinya emesis juga menurun. Komunikasi yang baik antara ibu hamil dan keluarga serta petugas kesehatan membantu penurunan kejadian emesis yang berlebihan atau tidak normal.

Maka dapat disimpulkan bahwa emesis dapat menimbulkan kekhawatiran pada primigravida maupun multigravida. Kekhawatiran yang dialami oleh primigravida menunjukkan kurangnya pengetahuan, informasi dan komunikasi antara wanita dan pemberi asuhan,
Sedangkan pada multigravida sudah mempunyai pengalaman, informasi dan pengetahuan tentang gejala emesis gravidarum sehingga mampu mengatasi gejalanya.

\section{Hubungan Pekerjaan Dengan Emesis Gravidarum}

Hasil analisis hubungan antara pekerjaan dengan emesis gravidarum diperoleh bahwa diantara responden yang mengalami emesis gravidarum tidak normal terdapat $70,5 \%$ (31 org) yang bekerja dan $32,6 \%$ (15 org) yang tidak bekerja. Hasil uji statistik diperoleh nilai $P$ - value $=0,001$, disimpulkan secara statistik ada hubungan yang signifikan antara pekerjaan dengan emesis gravidarum. Berdasarkan hasil analisis diperoleh pula nilai $O R=4,928$, artinya responden yang mempunyai pekerjaan mempunyai peluang 4,928 kali untuk mengalami emesis gravidarum tidak normal dibandingkan dengan responden yang tidak bekerja.

Hal ini sejalan dengan penelitian Irna, 2012 tentang emesis gravidarum di Seberang Ulu Palembang dari 65 responden didapatkan hasil ibu yang bekerja sebanyak 36 orang (55,4\%), sedangkan ibu yang tidak bekerja sebanyak 29 orang (44,6\%) (Anggraena, 2012).

Pekerjaan merupakan suatu yang penting dalam kehidupan dengan bekerja kita bias memenuhi kebutuhan (Winknjosastro, 2005). Suatu pekerjaan responden dalam penelitian dibagi menjadi dua yaitu responden bekerja dan tidak bekerja. Definisi bekerja responden melakukan kegiatan di rumah atau di tempat lain secara rutin atau berkala dengan tujuan untuk mendapatkan uang (Suniarti, 2007). Menurut Tiran, 2009 yang dikutip Henny, 2012 perjalanan ketempat kerja yang mungkin terburu-buru di pagi hari tanpa waktu yang cukup untuk sarapan dapat menyebabkan mual dan muntah. Tergantung pada sifat pekerjaan wanita, aroma, zat kimia, atau lingkungan dapat menambah rasa mual wanita dan menyebabkan mereka muntah. Merokok terbukti memperburuk gejala mual dan muntah, tetapi tidak jelas apakah ini disebabkan oleh efek olfaktorius 
(penciuman) atau efek nutrisi, atau apakah dapat dibuat asumsi mengenai hubungan antara kebiasaan praktik dan distres psikoemosional. Tentu saja banyak wanita yang mengalami mual dan muntah akan membenci bau asap rokok dan tembakao.

Jenis pekerjaan responden dalam penelitian ini sebagian besar adalah karyawan swasta, buruh dan pedagang pasar. Kondisi lingkungan kerja karyawan swasta yang bercampur dengan laki-laki perokok memicu terjadinya emesis. Sedangkan untuk pedagang pasar dan buruh, kondisi lingkungan yang tidak bersih, aroma aneka macam barang dagangan pasar juga memicu terjadinya emesis. Beban pikiran untuk wanita pekerja juga berpengaruh ke kondisi psikologis responden. Responden yang hamil pada usia muda bahkan tergolong remaja sebanyak 3 orang yaitu usia 15 tahun. Sebagian besar kehamilan remaja jarang mendapat konseling prekonsepsi karena kehamilannya tidak direncanakan. Konseling pada kehamilan tahap awal sanggat bermanfaat untuk mempersiapkan ibu hamil baik secara fisik maupun psikologis. Kecemasan yang terjadi pada wanita hamil usia dini lebih tinggi sehingga memicu terjadinya emesis berlebihan.

Emesis pemicu utama adalah hormon HCG, dimana pengendaliannya adalah pikiran manusia. Jika kondisi pikiran tidak baik maka akan memicu pengeluaran HCG yang berlebihan. Mual dan muntah selama kehamilan biasanya disebabkan oleh perubahan dalam sistem endokrin yang terjadi selama kehamilan, terutama disebabkan oleh tingginya fluktasi kadar HCG (human chorionic gonadotrophin), khususnya karena periode mual atau muntah gestasional yang paling umum adalah pada 12-16 minggu pertama, yang pada saat itu, HCG mencapai kadar tingginya. Perubahan hormon yang akan mengakibatkan pengeluaran asam lambung yang berlebihan, terutama di pagi hari . Perasaan mual dan muntah pada ibu hamil disebabkan karena selama hamil muda pergerakan usus menjadi lambat, karena pengaruh hormon hipofise (Suririnah, 2009).

Maka dapat disimpulkan bahwa pekerjaan mempunyai pengaruh terhadap emesis gravidarum. Lingkungan kerja yang sehat dan beban pekerjaan secara fisik dan psikis yang ringan akan menurunkan kejadian emesis berlebihan/tidak normal. Lingkungan kerja yang sehat dapat tercipta atas kerjasama semua karyawan atau orang yang ada dilingkungan tersebut dan didukung adanya kebijakan serta peraturan yang jelas dari manajerial institusi/kantor tersebut. Selain itu beban pekerjaan baik secara fisik maupun psikis juga menjadi perhatian bersama. Saat ini sudah ada peraturan pemerintah yang mengatur tentang pekerja wanita dalam situasi hamil, melahirkan dan menyusui. Jika hal ini diterapkan dengan baik dilingkungan kerja maka sangat bermanfaat bagi ibu hamil.

\section{Hubungan Stress Dengan Emesis Gravidarum}

Hasil analisis hubungan antara stress dengan emesis gravidarum diperoleh bahwa diantara responden yang mengalami emesis gravidarum tidak normal terdapat $71,8 \%$ (28 org) yang stress dan 35,3\% (18 org) yang tidak stress. Hasil uji statistik diperoleh nilai $P$ - value $=0,001$, disimpulkan secara statistik ada hubungan yang signifikan antara pekerjaan dengan emesis gravidarum. Berdasarkan hasil analisis diperoleh pula nilai $O R=4,667$, artinya responden yang mengalami stress mempunyai peluang 4,667 kali untuk mengalami emesis gravidarum tidak normal dibandingkan dengan responden yang tidak stress.

Hal ini sesuai dengan penelitian Puji Nur Khasanah, 2017 menyatakan Hasil penelitian ini menemukan bahwa stres signifikan dengan prevalensi emesis gravidarum dengan $\mathrm{p}$-value 0,024 Kesimpulan: Terdapat hubungan tingkat stress dengan kejadian emesis gravidarum pada ibu hamil trimester 1 di wilayah kerja Puskesmas 1 Cilongok Kabupaten Banyumas. Yeni pujiati, dkk, 2009 menyatakan hasil penelitian yaitu $30 \%$ mempunyai psikologis yang baik, 53\% tidak memiliki riwayat emesis, dan $53 \%$ primigravida. hasil analisis menyebutkan bahwa, psikologis, riwayat emesis, dan paritas merupakan faktor-faktor yang 
mempengaruhi emesis gravidarum pada ibu hamil.

Mual dan muntah juga berhubungan dengan tingkat stres saat mengalami kehamilan pertama. Pada ibu primigravida, faktor psikologik memegang peranan penting pada mual dan muntah. Takut terhadap kehamilan dan persalinan, takut terhadap tanggung jawab sebagai seorang ibu dapat menyebabkan konflik mental yang dapat memperberat mual dan muntah sebagai ekspresi tidak sadar terhadap penolakan untuk hamil.

Faktor selanjutnya kehamilan diusia kurang dari 20 tahun secara biologis belum optimal emosinya, cenderung labil, mentalnya belum matang sehingga mudah mengalami guncangan yang mengakibatkan kurangnya perhatian terhadap pemenuhan kebutuhan zat-zat gizi selama kehamilannya. Usia diatas 35 tahun juga tidak lepas dari faktor psikologis yang disebabkan oleh karena ibu belum siap hamil atau bahkan tidak menginginkan kehamilannya lagi sehingga akan merasa sedemikian tertekan dan menimbulkan stres pada ibu. Faktor usia sering dikaitkan dengan kesiapan mental ibu hamil tersebut untuk menjadi seorang ibu. Kesiapan mental biasanya kurang dimiliki oleh ibu dengan umur yang relatif muda.

Secara umum kondisi psikologis ibu hamil cukup labil. Ia dapat memiliki reaksi yang ekstrem dan susana hatinya kerap berubah dengan cepat. Reaksi emosional dan persepsi mengenai kehidupan juga dapat mengalami perubahan. Ia menjadi sangat sensitif dan cenderung bereaksi berlebihan. Seorang wanita hamil akan lebih terbuka terhadap dirinya sendiri dan suka berbagi pengalaman kepada orang lain. Ia merenungkan mimpi tidurnya, anganangannya, fantasinya, dan arti kata-katanya, objek, peristiwa, konsep abstrak, seperti kematian, kehidupan, keberhasilan, dan kebahagiaan. Ia dapat mengidentifikasi bentuk-bentuk fisik yang berhubungan erat dengan masa usia subur atau mencukupkan diri dengan kehidupan atau makanan. Selama kehamilan berlangsung, terdapat rangkaian proses psikologis khusus yang jelas, yang terkadang tampak berkaitan erat dengan perubahan biologis yang sedang terjadi termasuk rasa mual dan muntah.

Pada penelitian ini responden yang mengalami emesis normal sebanyak $27,8 \%$ (10 org) mengalami stress dan 69,8\% (30 orang) tidak mengalami stress. Karakteristik reponden yang mengalami stress rata-rata bekerja sebagai PNS dan wiraswasta. Latar belakang pendidikan sebagian besar adalah jenjang pendidikan SMA dan Sarjana. Stress dapat disebabkan oleh tekanan pekerjaan yang menumpuk pada responden, selain itu pengetahuan yang kurang tentang perubahan dan perawatan kehamilan meningkatkan kecemasan yang berpengaruh terhadap emesis.

Stres adalah suatu kondisi tegangan (tension) baik secara faal maupun psikologis yang di sebabkan oleh tuntutan dari lingkungan yang dipersepsi kan oleh penderitanya sebagai ancaman. Mengalami Stres adalah kondisi manusiawi. Pada satu sisi , stres membantu kita agar tetap termotivasi (eustres). Tetapi pada sisi lain jika kita terlalu banyak mendapatkan stres akan menurunkan kualitas kinerja kita (distres). Oleh karena itu, kemampuan mengelola strees menjadi penting untuk dilakukan agar tidak berlanjut ketingkat depresi. Kehamilan yang berjalan dengan nyaman akan meningkatkan kesejahteraan janin.

Maka dapat disimpulkan bahwa stress mempunyai pengaruh yang signifikan terhadap kejadian emesis gravidarum. Stress berhubungan dengan kondisi psikologis dan berpengaruh ke sistem hormonal. Secara fisiologis ibu hamil trimester I mengeluarkan hormon HCG yang menimbulkan rasa mual dan muntah. Dengan adannya stress maka pengeluaran HCG akan meningkat sehingga rasa mual dan muntah ini semakin tinggi, hal ini menjadi emesis gravidarum tidak normal atau hiperemesis gravidarum. Hiperemesis gravidarum akan berakibat pertumbuhan janin terhambat karena asupan nutrisi tidak ada buat janinnya. Persiapan yang cukup menjelang kehamilan baik secara fisik maupun psikis berupa pengetahuan yang baik tentang kehamilan, asupan nutrisi yang adekuat, dukungan keluarga, pendampingan tenaga kesehatan, pemeriksaan kesehatan 
rutin menjadi pokok agar komplikasi kehamilan baik bagi janin maupun ibu tidak terjadi.

\section{KESIMPULAN}

Hasil penelitian menunjukan bahwa lebih banyak responden yang memiliki usia tidak beresiko (usia 20 - 35 tahun) yaitu $70 \%$, lebih banyak responden yang memiliki status multigravida (kehamilan lebih dari 1 kali) yaitu $62,2 \%$, jumlah antara ibu hamil yang bekerja dan tidak bekerja hampir seimbang yaitu bekerja sebanyak 48,9\% dan tidak bekerja sebanyak $51,1 \%$, separuh ibu hamil mengalami stress sebanyak 56,7\% dan separuh ibu hamil mengalami emesis tidak normal sebanyak 51,1\%. Analisi lebih lanjutn menyimpulkan bahwa ada hubungan antara usia, pekerjaan dan stress dengan emesis gravidarum, dengan variabel yang paling dominan adalah Pekerjaan.

Hasil penelitian ini dapat menjadi masukan bagi bidan untuk lebih intensif melakukan konseling pra nikah dan saat ANC tentang pengetahuan perubahan fisiologis kehamilan terutama rasa mual dan muntah yang dialami saat trimester I menjadi lebih baik dan kondisi psikologis ibu lebih siap untuk menerima kehamilannya. Hasil penelitian ini dapat menjadi masukan agar penerapan Peraturan terkait kondisi kehamilan, persalinan dan menyusui bagi wanita pekerja di Kota Bandar Lampung lebih intensif sehingga kejadian stress dan beban kerja berlebih bagi wanita dapat dikurangi.

\section{DAFTAR PUSTAKA}

Bobak, Lowdermilk, \& Jensen. (2005). Buku ajar keperawatan maternitas (Maria A.Wijayarini, et.al. Terj). Jakarta: EGC.

Claudia Wijaya.(2017). Hubungan Antara Status Gravida dan Umur Ibu Hamil dengan Kejadian Emesis Gravidarum di RS Gotong Royong Surabaya. Skripsi. Universitas Katolik Widya Mandala. Surabaya.
Fauziyah Y. (2012). Obstetri patologi untuk mahasiswa kebidanan dan keperawatan. Yogyakarta: Nuha Medika.

Manuaba IBG. (2007. Buku ajar patologi obstetri untuk mahasiswa kebidanan. Jakarta: EGC. 2009. 41-46 p.

Manuaba IBG. (2007). Pengantar kuliah obstetri. Jakarta: EGC; 2007.

Prawiroharjo, S. (2009). Pelayanan Kesehatan Maternal dan Neonatal. Jakarta: Yayasan Bina Pustaka.

Rosdiana Said, dkk. (2013). Hubungan Usia Dan Stress Dengan Kejadian Emesisi Gravidarum Pada Ibu Primigravida di Puskesmas Kasi-Kasi Makasar. Jurnal Ilmiah Kesehatan Diagnosis. 1-6.

Runiari, N. (2010). Asuhan Keperawatan Pada Klie dengan Hiperemesis Gravidarum: Penerapan Konsep dan Teori Keperawatan. Jakarta:Penerbit Salemba Medika

Rustam. (2002). Sinopsis Obstetri Jilid I. Jakarta : EGC

Smith C, Crowther C, Willson K, Hotham N, McMillian V. 2004. A randomized controlled trial of ginger to treat nauseaand vomiting in pregnancy. Obstetric \& Gynecology Journal. 639645.

Supriyanto. W, (2009). Sehat dan Bugar Saat Hamil dan Melahirkan, Yogyakarta: Media Ilmu.

Suririnah. 2006. Morning Sickness dan Beberapa Penanganannya. http://www. in $\mathrm{foibu}$. c o m/t i p s infose ha t /mualmuntah.htm. Diakses pada 15 Maret 2018

Tiran D. (2009). Pendekatan pada kehamilan. Didalam: Mual dan muntah kehamilan. Jakarta: EGC.

Veenendaal, M.V., Van Abeelen, A.F., Painter, R.C., van der Post, J.A., Roseboom TJ. (2011). Consequences of hyperemesis gravidarum from offspring: a systematic review and meta- analysis. BJOG 118. 2011;(dikutip 2018 Sep 2). Diunduh dari:https://www.ncbi.nlm.nih.gov/pub $\operatorname{med} / 26801654$ 
Vicky Elsa. dkk (2012). Hubungan Paritas Ibu Hamil Trimester I Dengan Kejadian Emesis Gravidarum Di Puskesmas Teras. Jurnal Kebidanan.

Wiknjosastro. (2007). Ilmu Kebidanan. Jakarta:Bina Pustaka Sarwono Prawirohardjo
Yeni Pujiati. dkk . (2009). Faktor-faktor Yang Mempengaruhi Emesis Gravidarum Pada Ibu Hamil Trimester I di Puskesmas Ngampilan Yogyakarta. Repository. Universitas Aisyiyah Yogyakarta.

Yunia Mariatari, dkk. (2014). Hubungan Dukungan Suami, Usia Ibu dan Gravida Terhadap Kejadian Emesis Gravidarum. Jurnal Online Mahasiswa. 1-9. 